\title{
HUBUNGAN MOTIVASI OLAHRAGA DAN KEMAMPUAN MOTORIK DENGAN HASIL BELAJAR PENDIDIKAN JASMANI OLAHRAGA DAN KESEHATAN SISWA SEKOLAH DASAR NEGERI 16 SINTOGA KECAMATAN SINTUK TOBOH GADANG KABUPATEN PADANG PARIAMAN
}

\author{
Arie Asnaldi ${ }^{1}$, Zulman $^{2}$, Madri M $^{3}$ \\ Jurusan Pendidikan Olahraga, Program Studi Pendidikan Jasmani Kesehatan dan Rekreasi, Fakultas \\ Ilmu Keolahragaan, Universitas Negeri Padang, Jalan Prof. Dr. Hamka Air Tawar Barat, \\ Padang 25132, Indonesia.
}

E-mail: asnaldi@fik.unp.ac.id ${ }^{1}, \underline{\text { zulman@ fik.unp.ac.id }}{ }^{2}$

\begin{abstract}
Abstrak
Masalah dalam penelitian ini yaitu rendahnya hasil belajar pendidikan jasmani Olahraga dan kesehatan siswa SD Negeri 16 Sintoga Kec.Sintuk Toboh Gadang Kabupaten Padang Pariaman. Penelitian ini bertujuan untuk mengetahui hubungan motivasi Olahraga dan kemampuan motorik dengan hasil belajar pendidikan jasmani olahraga dan kesehatan siswa SD Negeri 16 Sintoga Kec. Sintuk Toboh Gadang Kabupaten Padang Pariaman.

Jenis penelitian ini adalah korelasional. Populasi dalam penelitian ini yaitu siswa di SD Negeri 16 Sintoga Kec. Sintuk Toboh Gadang Kabupaten Padang Pariaman yaitu berjumlah sebanyak 77 orang, terdiri dari kelas IV yang berjumlah sebanyak 39 orang dan kelas V berjumlah sebanyak 38 orang. Teknik pengambilan sampel menggunakan purposive sampling. Dengan demikian jumlah sampel di dalam penelitian ini adalah sebanyak 36 orang. Data motivasi olahraga di peroleh dari hasil penyebaran angket kepada siswa yang terpilih menjadi sampel, variabel kemampuan motorik di peroleh dari hasil pengukuran terhadap kemampuan motorik siswa dan data hasil belajar penjas orkes di peroleh dari nilai siswa yang tertera di dalam rapor. Data dianalisis dengan korelasi productmoment dan dilanjutkan dengan korelasi ganda.

Berdasarkanhasilanalisis data menunjukkan bahwa motivasi olahraga mempunyai hubungan secara signifikan, karena ditemukanr hitung $_{0,341>\mathrm{r}_{\text {tabel }}} 0,329$ dant $_{\text {hitung }}=2,11>\mathrm{t}_{\text {tabel }} 1,69 \alpha=0.05$. Variabel kemampuan motorik mempunyai hubungan secara signifikan karena ditemukan $r_{\text {hitung }} 0,402$ $>\mathrm{r}_{\text {tabel }} 0,329$ dant $_{\text {hitung }}=2,56>\mathrm{t}$ tabel $1,69 \alpha=0.05$ Sedangkan variabel motivasi olahraga dan kemampuan motorik secara bersama-sama mempunyai hubungan secara signifikan dengan hasil belajar pendidikan jasmani olahraga dan kesehatan dan diterima kebenarannya secara empiris, karena ditemukan $\mathrm{r}_{\text {hitung }}=0,487>\mathrm{r}_{\text {tabel }} 0,329$ dan $\mathrm{F}_{\text {hitung }}=5,13>\mathrm{F}_{\text {tabel }} 3,29$.
\end{abstract}

\section{PENDAHULUAN}

Pendidikan jasmani olahraga dan kesehatan merupakan salah satu mata pelajaran yang terdapat dalam kurikulum Sekolah Dasar. Menurut Mulyasa (2010:49) kelompok mata pelajaran pendidikan jasmani olahraga dan kesehatan pada SD/MI/SDLB dimaksud untuk "meningkatkan potensi fisik dan menanamkan sportifitas serta kesadaran hidup sehat". Artinya peserta didik setelah mendapat pembelajaran penjasorkes yang diberikan guru akan dapat memahami dan menerapkan kesadaran hidup sehat dan meningkatkan potensi fisik serta mempunyai sikap sportifitas yang tinggi.

Mengajar sering diistilahkan dengan pembelajaran dalam kontek standar proses pendidikan jasmani olahraga dan kesehatan tidak hanya sekedar menyampaikan materi pelajaran, tetapi juga dimaknai sebagai proses mengatur lingkungan supaya siswa belajar. Hal ini mengisaratkan bahwa dalam proses belajar mengajar siswa harus dijadikan sebagai pusat kegiatan.

Dengan demikian diharapkan akhir dari proses pembelajaran penjasorkes tersebut siswa akan mendapat atau memperoleh hasil belajar, setelah guru penjasorkes melakukan evaluasi atau penilaian. Dapat juga diartikan bahwa hasil dari suatu interaksi tindak belajar dan tindak mengajar adalah hasil belajar. Dari sisi guru tindak mengajar diakhiri dengan proses evaluasi hasil belajar, dari sisi siswa hasil belajar 
merupakan berakhirnya penggal dan puncak proses belajar.

Berdasarkan informasi dan wawancara penulis lakukan pada guru penjasorkes SD Negeri 16 Sintoga Kec.Sintuk Toboh Gadang Kabupaten Padang Pariaman, ternyata hasil belajar penjasorkes siswa masih banyak yang rendah, khususnya pada siswa kelas IV, kelas V. Gambaran data yang diberikan guru penjasorkes, dari 77 orang siswa hanya sebanyak 45 orang $(58,44 \%)$ hasil belajar penjasorkes siswa berada di atas nilai rata-rata kelas yaitu 7 dan sebanyak 32 orang $(41,56 \%)$ hasil belajar penjasorkes berada di bawah nilai rata-rata kelas.

Rendahnya hasil belajar penjasorkes siswa di SD Negeri 16 Sintoga Kec.Sintuk Toboh Gadang Kabupaten Padang Pariaman, mungkin disebabkan oleh beberapa faktor diantaranya adalah mungkin kemampuan guru dalam mengajar, pemilihan metoda dan media yang kurang tepat, sarana dan prasarana yang belum memadai, status gizi siswa yang buruk, tingkat kesegaran jasmani yang belum begitu baik, lingkungan belajar yang kurang kondusif, motivasi berolahraga yang rendah dan mungkin juga disebabkan kemampuan motorik atau gerak mereka yang rendah.

Setelah penulis mendapatkan informasi tentang hasil belajar penjasorkes siswa SD Negeri 16 Sintoga Kec.Sintuk Toboh Gadang Kabupaten Padang Pariaman, maka penulis melakukan observasi ke lapangan pada saat siswa mengikuti proses pembelajaran penjasorkes. Dari hasil observasi dan pengamatan tersebut, penulis menduga motivasi berolahraga dan kemampuan motorik siswa masih rendah.Hal ini terlihat dari penampilan dan sikap mereka ketika guru penjasorkes memberikan materi pembelajaran, banyak yang bermain sesuka hatinya, ada yang malas, sedikit saja bergerak sudah berhenti, geraknya tidak lincah, tidak mampu melakukan gerakan yang diajarkan guru dan sebagainya.

Di samping itu banyak siswa perempuan ketika jam istirahat hanya duduk sambil jajan, begitu juga siswa laki-laki hanya sebahagian kecil melakukan aktivitas bermain atau berolahraga dan sebagian lainnya duduk main game yang ada di handpone mereka, sehingga hal ini penulis berpraduga penampilan dan sikap serta kebiasaan siswa akan berpengaruh pada kemampuan motorik mereka, bahkan penulis cendrung mengatakan kemampuan motorik siswa rendah dan berakibat pada hasil belajar penjasorkes mereka, karena dalam pembelajaran penjasorkes banyak berhubungan dengan gerakan.

Dari uraian di atas, benar atau tidaknya dugaan penulis yang menyatakan rendahnya hasil belajar penjasorkes siswa SD Negeri 16 Sintoga Kec.Sintuk Toboh Gadang Kabupaten Padang Pariaman, ada hubungannya dengan motivasi berolahraga dan kemampuan motorik mereka. Menurut Dimyati dkk (2006:200) mengatakan bahwa "evaluasi hasil belajar merupakan proses untuk menentukan nilai belajar siswa melalui kegiatan penilaian dan/atau pengukuran hasil belajar".

Sedangkan ranah psikomotorik adalah yang berkenaan dengan hasil belajar keterampilan dan kemampuan bertindak, ada 6 aspek yakni gerakan refleks, keterampilan gerak dasar, kemampuan perseptual, keharmonisan atau ketepatan, gerakan keterampilan kompleks dan gerakan ekspresif dan interpretatif. Sementara Nana Sudjana (2009:22) mengatakan bahwa "hasil belajar adalah kemampuankemampuan yang dimiliki siswa setelah ia menerima pengalaman belajarnya".

Demikian dapat diartikan bahwa seseorang untuk mendapatkan hasil belajar pendidikan jasmani olahraga dan kesehatan yang didapat dari proses belajar merupakan hasil dari penguasaan tiga ranah tersebut yaitu ranah kognitif, afektif dan psikomotoris. Semua ranah tersebut yang menjadi evaluasi yang dilakukan guru penjasorkes untuk mengetahui apakah suatu tujuan pembelajaran di sekolah dapat dicapai dengan baik atau tidak dan siswa juga mengetahui sampai dimana usahan dan keberhasilan mereka dalam belajar.

Selanjutnya hasil belajar siswa tentu akan lebih baik, apabila di dukung oleh faktor kemampuan motorik yang dimiliki siswa. Sehingga dengan kemampuan motorik baik, mereka akan mudah melakukan keterampilan jasmani, olahraga yang merupakan materi dalam pembelajaran penjasorkes. Di samping itu siswa akan dapat menyelesaikan gerakan-gerakan atau keterampilan gerak dalam berbagai olahraga seperti olahraga permainan, senam dan atletik. Hal ini merupakan materi yang harus dipelajari dan dievaluasi setelah siswa mengalami belajar selama satu semester.

Selanjutnya anak-anak yang senang melakukan kegiatan berolahraga atau dapat dikatakan mereka memiliki motivasi yang tinggi, karena mereka berharap dapat mencapai 
kepuasan untuk mendapatkan nilai mata pelajaran pendidikan jasmani olahraga dan kesehatan (penjasorkes) karena dalam pembelajaran penjasorkes tersebut banyak menuntut kegiatan atau aktivitas olahraga.

Artinya mereka berolahraga ingin mengembangkan keterampilan dan kemampuan dengan motivasi yang tinggi ada hubungannya dengan harapann hasil belajar penjasorkes menjadi lebih baik. Di sekolah dasar penekanan pada tujuan untuk mengenal dan mengermari serta menyenangi olahraga. Misalnya saja olahraga pendidikan yang diberikan pada proses pembelajaran yang dirancang khusus dalam kurikulum di sekolah dasar yaitu dalam mata pelajaran pendidikan jasmani olahraga dan kesehatan, (penjasorkes) yang menekankan pencapaian tujuan pendidikan.

Luthan dkk, (1991:13) mengatakan bahwa: 1) Ciri-ciri hakiki dalam olahraga adalah: olahraga merupakan sub bagian dari permainan yang ditandai dengan kebebasan dan kegiatan sukarela tanpa paksaan, 2) ciri khas dalam olahraga, berorientasi pada kegiatan jasmani dalam wujud kemampuan motorik (gerak) atau dapat dikatakan olahraga menekankan pada kemampuan gerak ketimbang non motorik, 3) olahraga merupakan sebagai realitas atau olahraga dilakukan dalam suasana yang tak sebenarnya namun keterlibatan seseorang dalam olahraga merupakan sesuatu yang nyata.

Dalam kehidupan manusia gerak merupakan suatu kebutuhan dan mempunyai nilai yang sangat strategis bagi manusia dalam kehidupannya.Hal ini dapat dikatakan demikian karena melalui gerak manusia dapat mengatasi berbagai persoalan dalam hidupnya.

Gerak dibutuhkan manusia untuk bekerja dan mempertahankan hidupnya dari ancaman yang datang dari lingkungan, serta melalui gerak manusia dapat mengalami sendiri suatu pengalaman atau melalui geraknya manusia dapat menyakinkan dirinya terhadap sesuatu. Kiram (2000:5) menjelaskan bahwa: Di dalam belajar motorik, pengertian gerak tidak hanya dilihat dari perubahan tempat, posisi dan kecepatan tubuh manusia melakukan aksi-aksi dalam olahraga, tetapi gerak gerak juga diartikan atau dilihat sebagai hasil atau penampilan yang nyata dari proses-proses motorik.

Penampilan nyata maksudnya adalah gerak sebagai sesuatu yang bisa diamati, sedangkan motorik adalah suatu proses yang tidak dapat diamati dan merupakan penyebab terjadinya gerak.

Dengan demikian dapat dikatakan bahwa kemampuan motorik yang baik akan dapat mempermudah seseorang dalam belajar keterampilan gerak, begitu juga bagi siswa SD Negeri 16 Sinuk Toboh Gadang Kabupaten Padang Pariaman. Artinya siswa yang memiliki kemampuan motoriknya tinggi akan mudah melakukan keterampilan gerak, misalnya saja gerak dalam aktivitas sehari-harinya seperti belajar mata pelajaran penjasorkes.

Dengan sanggupnya anak-anak dalam melakukan keterampilan tentunya akan memotivasi anak untuk bergerak".Dengan demikian dapat diartikan bahwa gerak penting artinya dalam meningkatkan kemampuan motorik. Kemampuan motorik yang baik akan dapat meningkatkan hasil belajar penjasorkes, karena pembelajaran penjasorkes banyak menampilan gerak.

Maka jelaslah bahwa motorik adalah suatu peristiwa latin dalam bentuk wujud gerak seseorang, akibat adanya dorongan dalam diri yang dapat diamati. Misalnya saja seorang anak untuk belajar berjalan akan akan diamati dan hal ini merupakan suatu peristiwa laten akibat adanya dorongan untuk bergerak.

Kemampuan motorik merupakan kualitas kemampuan seseorang (individu) dalam melakukan gerakan yang dipandang sebagai landasan keberhasilan untuk menyelesaikan keterampilan gerak. Dengan demikian dapat dikatakan seseorang yang memiliki kemampuan motorik yang tinggi, diduga akan lebih berhasil dalam menyelesaikan tugas keterampilan motorik khusus. Hal ini tentunya dapat ditingkatkan melalui latihan-latihan dan dalam bermain.

Landasan berfikir dalam penelitian ini dapat digambarkan kerangka konseptual, yang berkaitan denganhubungan motivasi berolahraga dengan kemampuan motorik dengan hasil belajar penjasorkes siswa SD Negeri 16 Sintoga Kec.Sintuk Toboh Gadang Kabupaten Padang Pariaman. Hasil belajar adalah kemampuankemampuan yang dimiliki siswa setelah ia menerima pengalaman belajarnya".

Motivasi merupakan faktor psikis yang bersifat non-intelektual, peranannya yang khas yaitu dalam hal penumbuhan gairah, merasa senang dan semangat untuk berolahraga. Motivasi berolahraga bagi anak-anak sekolah dasar yang merupakan hal penting dalam 
mengikuti proses belajar penjasorkes. Sedangkan kemampuan motorik merupakan kualitas kemampuan siswa yang dapat mempermudah dalam melakukan keterampilan gerak.

Dengan demikian dapat dikatakan bahwa motivasi berolahraga dan kemampuan motorik yang baik akan dapat mendorong siswa untuk aktif berolahraga dan mempermudah siswa dalam belajar keterampilan gerak, begitu juga bagi siswa Sekolah Dasar Negeri16 Sintoga Kec.Sintuk Toboh Gadang Kabupaten Padang Pariaman.

Sehingga diduga berkemungkinan hasil belajar penjasorkes mereka dapat dicapai dengan baik. Dalam arti lain faktor motivasi berolahraga dan kemampuan motorik merupakan dua faktor yang diduga ada hubungannya dengan hasil belajar penjasorkes siswa.

\section{METODOLOGI}

Jenis penelitian yang dilakukan adalah korelasional yang bertujuan untuk melihat hubungan antara variabel yaitu: variabel bebas motivasi berolahraga (X1) dan kemampuan motorik (X2), sedangkan variabel terikat adalah hasil belajar penjasorkes siswa (Y) SD Negeri 16 Sintoga Kec.Sintuk Toboh Gadang Kabupaten Padang Pariaman.

Tempat penelitian ini dilaksanakan di SD Negeri 16 Sintoga Kec.Sintuk Toboh Gadang Kabupaten Padang Pariaman. Sedangkan waktu penelitian ini akan dilakukan setelah seminar proposal disetujui. Populasi merupakan wilayah generalisasi yang terdiri dari objek atau subjek yang menjadi kuantitas dan karakteristik tertentu yang ditetapkan oleh peneliti dan kemudian ditarik kesimpulannya".

Populasi dalam penelitian ini adalah siswa SD Negeri 16 Sintoga Kec.Sintuk Toboh Gadang Kabupaten Padang Pariaman yaitu berjumlah sebanyak 77 orang, terdiri dari kelas IV yang berjumlah sebanyak 39 orang dan kelas $\mathrm{V}$ berjumlah sebanyak 38 orang. Untuk lebih jelasnya rincian tentang jumlah populasi dalam penelitian ini dapat dilihat pada Tabel.1 di halaman berikutnya.

Tabel 1. Populasi Penelitian

\begin{tabular}{|c|c|c|c|c|}
\hline No. & Kelas & Laki-Laki & Perempuan & Jumlah \\
\hline 1 & IV & 22 orang & 17 orang & 39 orang \\
\hline 2 & V & 14 orang & 24 orang & 38 orang \\
\hline \multicolumn{2}{|c|}{ Jumlah } & 36 orang & 41 orang & 77 orang \\
\hline
\end{tabular}

Sampel secara sederhana diartikan sebagai bagian dari populasi yang akan dijadikan sebagai sumber data dalam suatu penelitian.
Sampel dalam penelitian ini diambil dengan menggunakan teknik purposive sampling. Maka sampel yang diambil dalam penelitian ini hanya siswa yang laki-laki saja, dengan pertimbangan perbedaan kemampuan kondisi fisik siswa , agar populasi homogen waktu dan keterbatasan yang penulis miliki. Dengan demikian jumlah sampel dalam penelitian ini berjumlah sebanyak 36 orang siswa laki-laki, dengan rincian 22 orang dari kelas IV dan 14 orang dari kelas V. Untuk lebih jelasnya dapat dilihat pada tabel 2 di bawah ini.

Tabel 2. Sampel Penelitian

\begin{tabular}{|c|c|c|}
\hline No. & Kelas & Jumlah \\
\hline 1 & IV & 22 orang \\
\hline 2 & V & 14 orang \\
\hline & Jumlah & 36 orang \\
\hline
\end{tabular}

Jenis data dalam penelitian ini adalah data primer yang berasal dari: hasill penyebaran angket untuk mendapatkan data motivasi berolahraga dan hasil belajar penjasorkes diperoleh dari guru penjas, serta pengukuran terhadap kemampuan motorik siswa. Sedangkan sumber data dalam penelitian ini yaitu siswa SD Negeri 16 Sintoga Kec.Sintuk Toboh Gadang Kabupaten Padang Pariaman yang terpilih sebagai sampel.

Teknik dan alat pengumpul data yang digunakan adalah:

1. Motivasi Berolahraga

Untuk memperoleh data motivasi berolahraga digunakan angket yang disebarkan kepada siswa yang terpilih menjadi sampel dalam penelitian. Angket yang disebarkan berisi pertanyaan-pertanyaan yang berdasarkan pada indikator dari masalah yang diteliti yakni motivasi berolahraga.Angket ini berupa isian tertutup, dimana jawaban dari pertanyaan yang diajukan jawabannya telah disediakan dan responden hanya memilih salah satu alternatif jawaban tersebut. Untuk menjawab angket di dalam penelitian ini digunakan 2 (dua) kategori jawaban menurut (Sugiyono, 2008:139) yaitu: Ya (1) dan Tidak (0).

2. Tes Kemampuan Motorik untuk siswa Sekolah Dasar (SD) menurut Winarno (2006:87). Adapun rangkaian tes kemampuan motorik tersebut yakni sebagai berikut:

\section{a. Tes koordinasi mata kaki}

Tujuan tes ini untuk mengukur koordinasi mata kaki siswa (teste) dalam bergerak, tes ini digunakan untuk anak berusia 10-15 tahun. Alat dan perlengkapan : kapur atau pita untuk membuat garis, formulir dan alat tulis, sasaran berbentuk lingkaran 
terbuat dari kertas dengan diameter $65 \mathrm{~cm}$ dengan ketinggian 1,25 meter dan jarak antara teste dengan sasaran 2 meter dan dibatasi dengan pita.

Pelaksanaan: (1) Sasaran ditempel pada tembok dengan ketinggian bawahnya setinggi 1,25 meter, teste berdiri dibelakang garis pembatas dengan jarak teste 2 meter dari tembok sasaran. (2) teste melaksanakan tes dengan cara melambungkan bola ke atas, menendang bola ke sasaran, menimbang bola yang memantul dari sasaran sebelum bola jatuh di lantai dan menangkapnya kembali. (3) sebelum melaksanakan tes teste diberi kesempatan untuk mencoba agar beradaptasi dengan tes tersebut. (4) tes dianggap berhasil apabila bola yang ditendang mengenai sasaran, bola yang memantul dapat di timang dan di tangkap kembali di depan garis batas. (5) teste memperoleh kesempatan melakukan tes 10 kali menggunakan kaki kanan dan 10 kali menggunakan kaki kiri.

Penskoran, (1) satu tendangan yang mengenai sasaran dan dapat di tangkap dengan benar memperoleh skor 1 (satu).(2) jumlah skor yang diperoleh siswa (teste) adalah tendangan yang mengenai sasaran, di timang dan mampu ditangkap kembali oleh siswa, (3) jumlah skor tertinggi yang mampu diraih teste adalah 20 . Untuk lebih jelasnya pelaksanaan tes koordinasi mata kaki dapat dilihat pada gambar 2 .

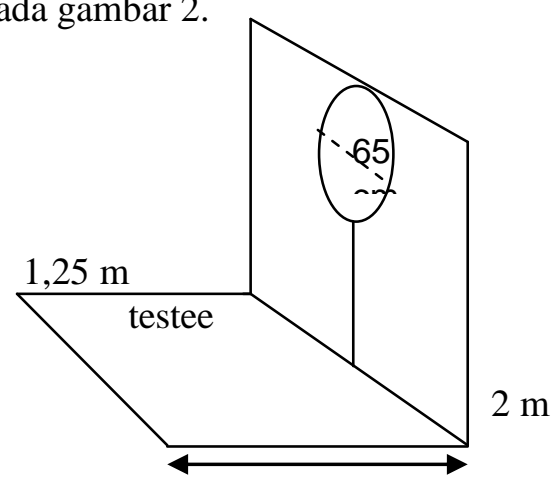

Gambar 2. Sasaran Tes Koordinasi Mata Kaki

\section{b. Tes Kelincahan (Shuttle Run 4 x 10 Meter)}

Tes ini bertujuan untuk mengukur kelincahan siswa dalam bergerak mengubah arah. Tingkat usia dari anak usia 9 tahun sampai dengan mahasiswa. Alat / perlengkapan yang dibutuhkan adalah:

1) Stopwatch sesuai dengan keperluan

2) Formulir dan alat tulis
3) Lapangan: Lintasan lari yang datar berjarak 10 meter dengan kedua ujungnya dibatasi oleh garis lurus. Pada kedua ujung lintasan dibuat setengah lingkaran dengan jari-jari 30 $\mathrm{cm}$, untuk tempat balok-balok (Gambar 3).

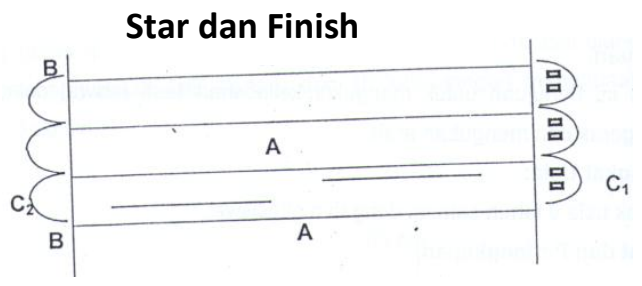

Gambar 3. Lintasan Shuttle Run Sumber: (Winarno, 2006)

4) Petugas: Stater 1 orang, pengambil waktu menurut keperluan, pengawas 1 orang dan pencatat 1 orang.

5) Prosedur pelaksanaan:

a) Start dilakukan dengan start berdiri

b) Pada aba-aba "bersedia" testi dengan salah satu ujung jari kaki sedekat mungkin dengan garis start (Gambar 4)

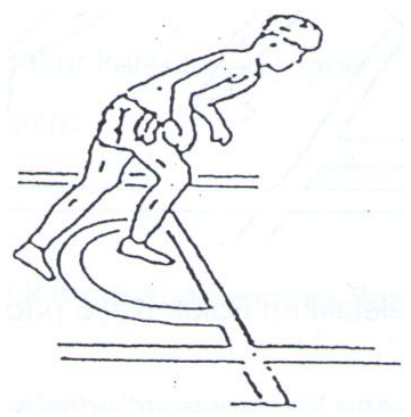

Gambar 4. Testi Berdiri di Depan Garis Start Sumber: (Winarno, 2006)

c) Setelah tenang, aba-aba "siap" diberikan testi siap untuk berlari.

d) Pada aba-aba "Ya" testi segera berlari menuju garis batas untuk mengambil dan memindahkan balok pertama ke setengah lingkaran yang berada ditempat garis start (Gambar 5)

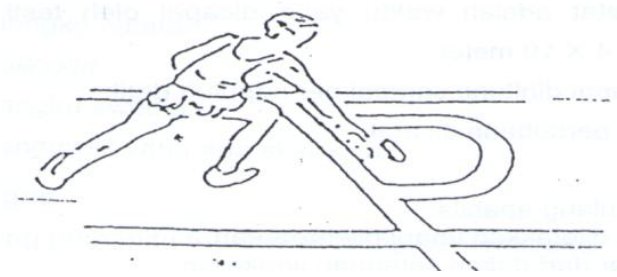


Gambar 5. Testi Mengambil Balok Kayu

Sumber: (Winarno, 2006)

e) Kemudian kembali lagi menuju ke garis batas untuk mengambil dan memindahkan balok kedua ketengah lingkaran yang berada ditempat garis start (Gambar 6)

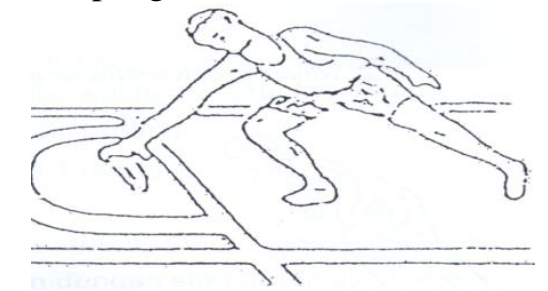

Gambar 6. Testi Meletakkan Balok Kayu pada $1 / 2$ Lingkaran.

Sumber: (Winarno, 2006)

f) Bersamaan dengan aba-aba "Ya", stopwatch dijalankan dan dihentikan pada saat terakhir diletakkan, stopwatch dihentikan.

Catatan: Balok kayu dapat diganti dengan benda lain yang mendekati ukuran balok kayu tersebut. Setiap testi diberi kesempatan melakukan 2 kali, balok harus diletakan tidak boleh dilemparkan dan balok diletakan di dalam setengah lingkaran.

6) Pencatatan hasil:

a) Hasil dicatat adalah waktu yang dicapai oleh testi untuk menempuh jarak 4 X 10 meter.

b) Waktu yang dicapai dihitung sampai per sepuluh detik

c) Hasil kedua percobaan dicatat

\section{c. Tes Kelentukan Tegak}

Untuk mengukur kelentukan tubuh dilakukan dengan menggunakan sits and reach test menurut Winarno (2006:93) dengan menggunakan alat Flexiometer dengan Validitas tes berupa Logical Validity dan Reliabitas yang digunakan adalah tes ulang (test re-test). Dengan petunjuk pelaksanaan yaitu:

a) Perlengkapan yaitu blangko catatan, ballpoint, bangku swedia dan penggaris yang ada skalanya.

b) Petugas yaitu seorang pemandu tes dan seorang pencatat skor.

c) Pelaksanaan tes yaitu: testi duduk telunjur, kedua tungkai lurus, telapak kaki menempel penuh pada bangku swedia, testi dengan kedua tangannya mencoba meraih atau meletakkan jari-jari tangan ke depan pada tempat yang telah ditentukan sejauh mungkin dan dipertahankan selama tiga detik. Tidak diperkenankan berlatih, diberikan tiga kesempatan melakukan tes.

d) Penilaian yaitu skor yang dicatat berupa angka yang mampu diraih oleh testi dari jarak terjauh dalam tiga kali pelaksanaan. Untuk lebih jelasnya dapat dilihat pada gambar 6 di bawah ini.

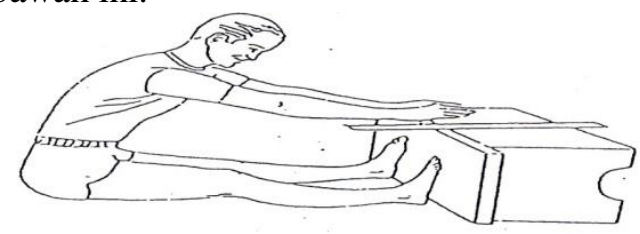

Gambar 7.Sit and Reach Test

3. Hasil belajar pendidikan jasmani olahraga dan kesehatan siswa diperoleh dari nilai siswa yang tertera di dalam rapor

Uji persyaratan analisis terlebih dahulu yang dilakukan dengan uji normalitas dengan menggunakan uji liliefors.

Setelah dilakukan uji persyaratan analisis, maka dilakukan uji hipotesis untuk mengetahui beberapa besar hubungan variabel bebas dengan variabel terikatdengan menggunakan rumus korelasi product moment.

\section{HASIL DAN PEMBAHASAN}

Variabel yang diteliti di dalam penelitian ini sebagai variabel bebas adalah:motivasi olahraga $\left(X_{1}\right)$ dan kemampuan motorik $\left(X_{2}\right)$, sedangkan sebagai variabel terikat adalah hasil belajar pendidikan jasmani olahraga dan kesehatan di SD Negeri 16 Sintoga Kec.Sintuk Toboh Gadang Kabupaten Padang Pariaman. Selanjutnya akan diuraikan hasil penelitian yang mencakup: deskripsi data, uji persyaratan analisis hipotesis, uji hipotesis dan pembahasan.

Berdasarkan hasil datamotivasi olahraga dari 36 orang siswa di SD Negeri 16 Sintoga Kec.Sintuk Toboh Gadang Kabupaten Padang Pariaman, didapatkan skor tertinggi motivasi olahraganya adalah 29 dan skor terendah 16, sedangkan range (jarak pengukuran) yaitu 13.

Berdasarkan data kelompok tersebut diperoleh nilai rata-rata hitung (mean) adalah 23,19, dan nilai tengah (median) 23. Simpangan baku (standar deviasi) adalah sebesar 2,89. Selanjutnya distribusi frekuensi hasil datamotivasi olahraga siswa di SD Negeri 16 Sintoga Kec.Sintuk Toboh Gadang Kabupaten Padang Pariamantersebut dapat dilihat pada tabel 3 di halaman berikutnya.

\section{Tabel 3.}


Distribusi Frekuensi Hasil Data Motivasi Olahraga Siswa di SD Negeri 16 Sintuk Toboh Gadang

\begin{tabular}{|c|c|c|c|}
\hline $\begin{array}{c}\text { Kelas } \\
\text { Interval }\end{array}$ & Kategori & $\begin{array}{c}\text { Frekuensi } \\
\text { Absolut }\end{array}$ & $\begin{array}{c}\text { Frekuensi } \\
\text { Relatif }\end{array}$ \\
\hline $27-29$ & Baik Sekali & 3 & $8,33 \%$ \\
\hline $24-26$ & Baik & 14 & $38,89 \%$ \\
\hline $21-23$ & Sedang & 14 & $38,89 \%$ \\
\hline $18-20$ & Kurang & 3 & $8,33 \%$ \\
\hline $15-17$ & $\begin{array}{c}\text { Kurang } \\
\text { Sekali }\end{array}$ & 2 & $5,56 \%$ \\
\hline \multicolumn{2}{|c|}{ Jumlah } & 36 & $100 \%$ \\
\hline
\end{tabular}

Pada Tabel 3 di atas, maka dapat disimpulkan bahwa dari 36 orang siswa, untuk variabel motivasi olahraga, siswa yang memiliki kelas interval $15-17$ adalah 2 orang $(5,56 \%)$, kelas interval $18-20$ adalah 3 orang $(8,33 \%)$ dan kelas interval 21 - 23 adalah sebanyak 14 orang $(38,89 \%)$. Sedangkan yang memiliki kelas interval $24-26$ adalah sebanyak 14 orang $(38,89 \%)$ dan kelas interval $27-29$ adalah 3 orang $(8,33 \%)$. Untuk lebih jelasnya dapat dilihat pada gambar 8 .

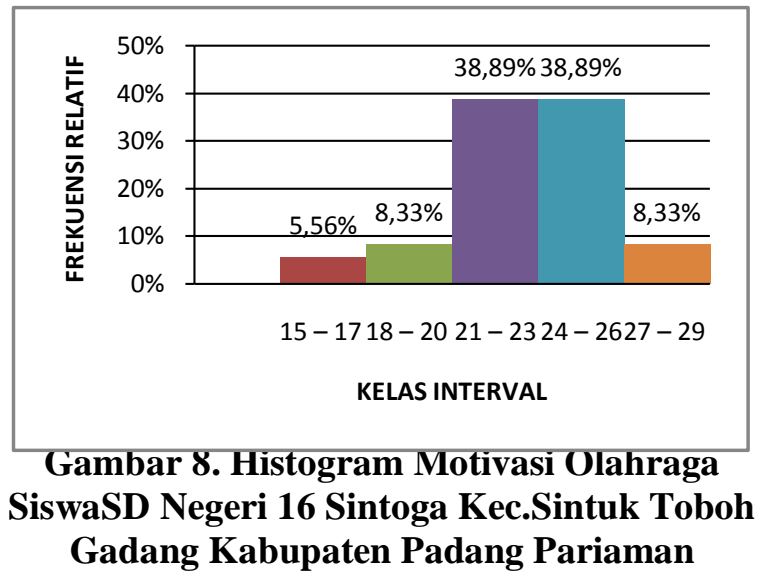

Selanjutnya berdasarkan hasil data yang telah dikemukakan, maka dapat disimpulkan bahwasiswa yang memiliki motivasi olahraga skor di atas kelompok rata-rata adalah sebanyak 17 orang $(47,22 \%)$ dan motivasi olahraga skor dalam kelompok rata-rata adalah 5 orang $(13,89 \%)$. Sedangkan untuk skor di bawah kelompok rata-rata yaitu sebanyak 14 orang $(38,89 \%)$.

\section{Kemampuan Motorik}

Hasil data variabel kemampuan motorik dari 36 orang siswa di SD Negeri 16 Sintoga Kec.Sintuk Toboh Gadang Kabupaten Padang Pariaman, didapatkan skor tertinggi adalah 20 dan skor terendah yaitu 11 . Sedangkan range (jarak pengukuran) dari kemampuan motorik tersebut adalah 9 .
Berdasarkan data kelompok untuk variabel kemampuan motorik, diperoleh nilai rata-rata hitung (mean) adalah 16,67 dan nilai tengah (median)nya adalah 17. Sedangkan simpangan baku (standar deviasi) adalah 2,12. Selanjutnya distribusi frekuensi hasil datakemampuan motorik siswaSD Negeri 16 Sintoga Kec.Sintuk Toboh Gadang Kabupaten Padang Pariaman tersebut dapat dilihat pada tabel 4 di bawah ini.

Tabel 4. Distribusi Hasil Data

Kemampuan Motorik Siswa di SD Negeri 16 sintoga Kabupaten Padang Pariaman

\begin{tabular}{|c|c|c|c|}
\hline $\begin{array}{c}\text { Kelas } \\
\text { Interval }\end{array}$ & Kategori & $\begin{array}{c}\text { Frekuensi } \\
\text { Absolut }\end{array}$ & $\begin{array}{c}\text { Frekuensi } \\
\text { Relatif }\end{array}$ \\
\hline $19-20$ & $\begin{array}{c}\text { Baik } \\
\text { Sekali }\end{array}$ & 9 & $25 \%$ \\
\hline $17-18$ & Baik & 12 & $33,33 \%$ \\
\hline $15-16$ & Sedang & 10 & $27,78 \%$ \\
\hline $13-14$ & Kurang & 4 & $11,11 \%$ \\
\hline $11-12$ & $\begin{array}{c}\text { Kurang } \\
\text { Sekali }\end{array}$ & 1 & $2,78 \%$ \\
\hline Jumlah & 36 & 100 & \multicolumn{2}{|c|}{} \\
\cline { 1 - 2 } & & &
\end{tabular}

Berdasarkan pada Tabel 4 di halaman, maka dapat disimpulkan bahwa dari 36 orang siswa yang terpilih menjadi sampel dalam penelitian ini, yang memiliki kemampuan motorik untuk kelas interval 11 - 12 yaitu hanya 1 orang $(2,78 \%)$, kelas interval $13-14$ adalah 4 orang $(11,11 \%)$ dan kelas interval 15 - 16 yaitu sebanyak 10 orang $(27,78 \%)$. Sedangkan untuk kelas interval 17 - 18 adalah sebanyak 12 orang $(33,33 \%)$ dan kelas interval $19-20$ adalah sebanyak 9 orang $(25 \%)$. Untuk lebih jelasnya variabel kemampuan motorik tersebut dapat dilihat pada gambar 9 .

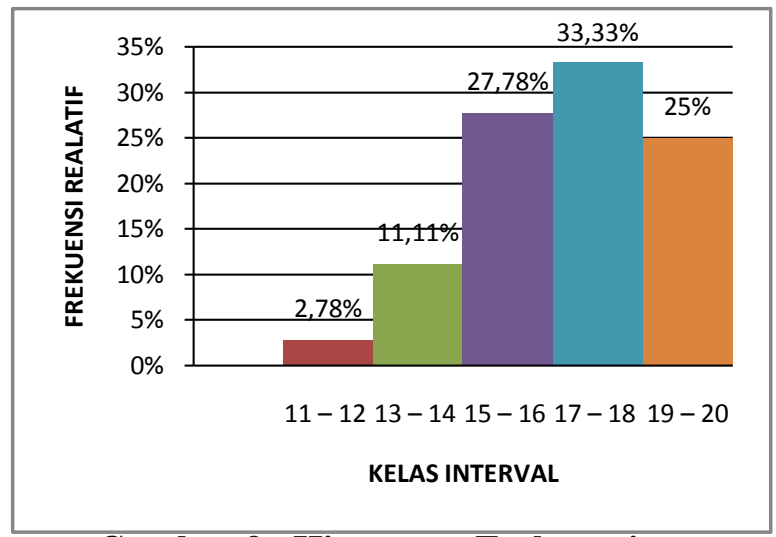

\section{Gambar 9. Histogram Frekuensi Kemampuan Motorik}

Berdasarkan uraian penskoran tentang variabel kemampuan motorik siswa di SD Negeri 16 Sintoga Kec.Sintuk Toboh Gadang Kabupaten Padang Pariaman yang telah dikemukakan di atas, maka dapat disimpulkan bahwasiswa yang memiliki kemampuan motorik 
dengan skor di atas kelompok rata-rata adalah sebanyak 10 orang $(27,78 \%)$ dan skor dalam kelompok rata-rata adalah sebanyak 11 orang $(30,56 \%)$.

Sedangkan untuk skor di bawah kelompok rata-rata yaitu sebanyak 15 orang $(41,67 \%)$.

\section{Hasil Belajar Pendidikan Jasmani Olahraga dan Kesehatan}

Berdasarkan data hasil belajar penjasorkes dari 36 orang siswa di SD Negeri 16 Sintoga Kec.Sintuk Toboh Gadang Kabupaten Padang Pariaman, didapatkan skor tertinggi adalah 78 dan skor terendah yaitu 64, sedangkan range (jarak pengukuran) adalah 14. Berdasarkan data kelompok yang telah diuraikan di atas, maka diperoleh rata-rata hitung (mean) 70,50, nilai tengah (median) adalah 70, dan simpangan baku (standar deviasi) 4,02. Selanjutnya distribusi datahasil belajar pendidikan jasmani olahraga dan kesehatan di SD Negeri 16 Sintoga Kec.Sintuk Toboh Gadang Kabupaten Padang Pariaman tersebut dapat dilihat pada tabel 5.

Tabel 5. Distribusi Frekuensi DataHasil Belajar Penjasorkes

\begin{tabular}{|c|c|c|c|}
\hline $\begin{array}{c}\text { Kelas } \\
\text { Interval }\end{array}$ & Kategori & $\begin{array}{c}\text { Frekuensi } \\
\text { Absolut }\end{array}$ & $\begin{array}{c}\text { Frekuensi } \\
\text { Relatif }\end{array}$ \\
\hline $76-78$ & Baik Sekali & 4 & $11,11 \%$ \\
\hline $73-75$ & Baik & 9 & $25 \%$ \\
\hline $70-72$ & Sedang & 10 & $27,78 \%$ \\
\hline $67-69$ & Kurang & 6 & $16,67 \%$ \\
\hline $64-66$ & $\begin{array}{c}\text { Kurang } \\
\text { Sekali }\end{array}$ & 7 & $19,44 \%$ \\
\hline \multicolumn{2}{|r|}{ Jumlah } & 36 & $100 \%$ \\
\hline
\end{tabular}

Berdasarkan Tabel 5 di atas, dapat disimpulkan bahwa dari 36 orang siswa, yang memiliki datahasil belajar penjasorkes dengan kelas interval 64 - 66 adalah 7 orang $(19,44 \%)$, kelas interval 67 - 69 adalah 6 orang $(16,67 \%)$ dan kelas interval 70 - 72 adalah sebanyak 10 orang $(27,78 \%)$. Sedangkan kelas interval 73 75 adalah sebanyak 9 orang $(25 \%)$ dan kelas interval 76 - 78 adalah 4 orang $(11,11 \%)$. Untuk lebih jelasnya variabel hasil belajarpenjasorkes siswa di SD Negeri 16 Sintoga Kec.Sintuk Toboh Gadang Kabupaten Padang Pariamandapat dilihat histogram pada gambar 10 berikut.

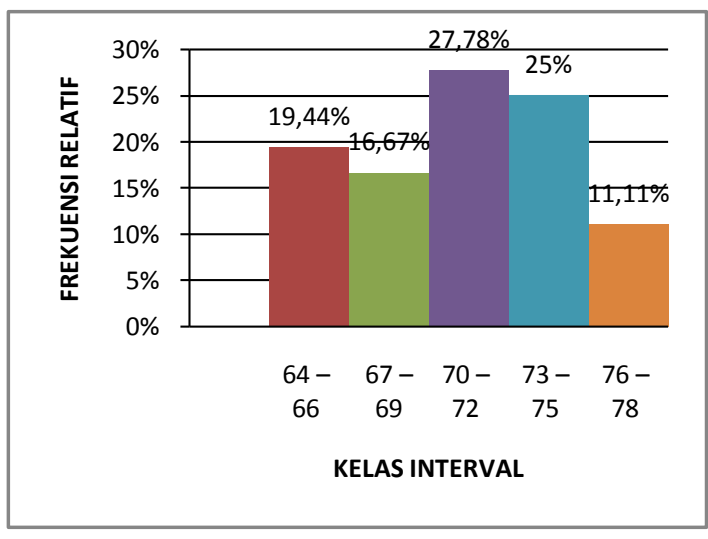

\section{Gambar 10. Histogram Frekuensi Hasil BelajarPenjasorkes}

Berdasarkan data tentang hasil belajar penjasorkes yang telah dikemukakan di atas, maka dapat disimpulkan bahwa siswadi SD Negeri 16 Sintoga Kec.Sintuk Toboh Gadang Kabupaten Padang Pariamanyang memiliki hasil belajar, dengan skor di atas kelompok rata-rata adalah sebanyak 14 orang $(38,89 \%)$ dan yang memiliki hasil belajar skor dalam kelompok ratarata hanya 1 orang $(2,78 \%)$. Sedangkan hasil belajar penjasorkes untuk skor di bawah kelompok rata-rata yaitu sebanyak 21 orang $(58,33 \%)$.

\section{B. Uji Persyaratan Analisis}

Sebelum melakukan pengujian terhadap hipotesis yang diajukan dalam penelitian ini, maka terlebih dahulu di lakukan uji persayaratan analisis dengan uji normalitas datauntuk mengetahui apakah data dari variabel yang diteliti berdistribusi normal atau tidak dapat digunakan uji Lilliefors. Hipotesis uji Lilliefors: $\mathrm{H}_{\mathrm{o}} \quad: \mathrm{L}_{\mathrm{o}}<\mathrm{L}_{\mathrm{t}}$ data berdisribusi normal $\mathrm{H}_{\mathrm{a}} \quad: \mathrm{L}_{\mathrm{o}}>\mathrm{L}_{\mathrm{t}}$ data tidak berdistribusi normal

Tabel 6. Rangkuman Uji Normalitas Data

\begin{tabular}{|l|c|c|c|}
\hline \multicolumn{1}{|c|}{ Variabel } & $\mathbf{L}_{\mathbf{0}}$ & $\mathbf{L}_{\mathbf{t}}$ & Kesimpulan \\
\hline Motivasi olahraga $\left(\mathrm{X}_{1}\right)$ & 0,083 & & \\
\cline { 1 - 2 } $\begin{array}{l}\text { Kemampuan motorik } \\
\left(\mathrm{X}_{2}\right)\end{array}$ & 0,130 & \multirow{2}{*}{0,148} & Normal \\
\cline { 1 - 2 } Hasil belajar (Y) & 0,131 & & \\
\hline
\end{tabular}

Berdasarkan pada tabel 6 di atas, ternyata hasil uji Lilliefors yang di observasi $\mathrm{L}_{\mathrm{o}}<\mathrm{L}_{\mathrm{t}}$ $\alpha=0.05)$, jika $\mathrm{L}_{\mathrm{o}}$ lebih kecil dari $\mathrm{L}_{\mathrm{t}}$ hal ini berarti ketiga data variabel yang diteliti dalam penelitian ini yaitu motivasi olahraga, kemampuan motorik dan hasil belajar penjasorkes adalah berdistribusi normal.

\section{Uji Hipotesis}

\section{Uji Hipotesis Penelitian Pertama $\left(X_{1}\right.$ dengan $\mathbf{Y}$ )}

Hipotesis pertama yang diajukan dalam penelitian ini adalah Terdapat hubungan yang signifikan antara motivasi olahragadenganhasil belajar penjasorkes siswa di SD Negeri 16 Sintoga Kec.Sintuk 
Toboh Gadang Kabupaten Padang Pariaman.Berdasarkanuji besarnya koefisien korelasi, dilakukan analisis korelasi product moment dan untuk menguji keberartian (signifikan) koefisien korelasi dilanjutkan dengan uji t korelasi.

Hasil analisis korelasi antara motivasi olahraga $\left(\mathrm{X}_{1}\right)$ dengan hasil belajarpenjasorkes siswa di SD Negeri 16 Sintoga Kec.Sintuk Toboh Gadang Kabupaten Padang Pariaman (Y) adalah diperoleh $r_{\text {hitung }} 0,341>r_{\text {tabel }} 0,329$ artinya terdapat hubungan yang signifikan antara motivasi olahragadenganhasil belajarpenjasorkes siswa di SD Negeri 16 Sintoga Kec.Sintuk Toboh Gadang Kabupaten Padang Pariaman. Untuk menguji signifikan koefisien korelasi motivasi olahragadengan hasil belajarpenjasorkes tersebut dilakukan uji t. Uji t tersebut dapat dilihat pada tabel 6 .

Tabel 7. Rangkuman Uji Keberartian

Koefisien KorelasiAntara Variabel

Motivasi olahraga DenganHasil belajarPenjasorkes

\begin{tabular}{|c|l|c|c|c|}
\hline $\begin{array}{l}\text { Koefisien } \\
\text { Korelasi }\end{array}$ & $\begin{array}{l}\text { Koefisien } \\
\text { Determinasi }\end{array}$ & $\begin{array}{c}\mathbf{t} \\
\text { hitung }\end{array}$ & $\begin{array}{c}\mathbf{t} \\
\text { tabel }\end{array}$ & Kesimpulan \\
\hline 0,341 & 0,1163 & 2,11 & 1,69 & Signifikan \\
\hline
\end{tabular}

Berdasarkan tabel 7 di atas, ternyata $\mathrm{t}_{\text {hitung }}=2,11>\mathrm{t}_{\text {tabel }} 1,69 \alpha=0.05$. Dengan demikian dapat disimpulan bahwa terdapat hubungan yang berarti (signifikan) antara motivasi olahraga dengan hasil belajar penjasorkes di SD Negeri 16 Sintoga Kec.Sintuk Toboh Gadang Kabupaten Padang Pariaman, diterima kebenarannya secara empiris.

\section{Uji Hipotesis Penelitian Ke Dua $\left(X_{2}\right.$ dengan} Y)

Hipotesis kedua yang diajukan dalam penelitian ini adalah Terdapathubungan yang signifikan antara kemampuan motorik denganhasil belajar penjasorkes di SD Negeri 16 Sintoga Kec.Sintuk Toboh Gadang Kabupaten Padang Pariaman. Untuk melihatbesarnya koefisien korelasi adalah dengan menggunakan analisis korelasiproduct moment dan untuk menguji keberartian (signifikan) koefisien korelasi dilanjutkan dengan uji t korelasi.

Berdasarkan hasil analisis korelasi antara kemampuan motorik $\left(\mathrm{X}_{2}\right)$ dengan hasil belajar penjasorkes (Y) diperoleh $r_{\text {hitung }} 0,402>r_{\text {tabel }}$ 0,329 , artinya terdapat hubungan yang signifikan antara kemampuan motorik dengan hasil belajar penjasorkes siswa di SD Negeri 16 Sintoga Kec.Sintuk Toboh Gadang Kabupaten Padang Pariaman. Untuk menguji signifikan koefisien korelasi antara kemampuan motorik dengan hasil belajarpenjasorkes siswa di SD Negeri 16 Sintoga Kec.Sintuk Toboh Gadang Kabupaten Padang Pariaman dilakukan uji t.

Untuk lebih jelasnya hasil rangkuman uji $\mathrm{t}$ atau uji koefisien korelasi antara kemampuan motorik dengan hasil belajarpenjasorkes di SD Negeri 16 Sintoga Kec.Sintuk Toboh Gadang Kabupaten Padang Pariamantersebut, dapat dilihat pada tabel 8.

Tabel 8. Rangkuman Uji Keberartian

Koefisien Korelasi Antara Variabel

Kemampuan Motorik Dengan Hasil belajar

Penjasorkes

\begin{tabular}{|c|c|c|c|c|}
\hline $\begin{array}{c}\text { Koefisien } \\
\text { Korelasi }\end{array}$ & $\begin{array}{l}\text { Koefisien } \\
\text { Determinasi }\end{array}$ & $\begin{array}{c}\mathbf{t}_{\text {hitun }} \\
\mathbf{g}\end{array}$ & $\begin{array}{c}\mathbf{t} \\
\text { tabel }\end{array}$ & $\begin{array}{c}\text { Kesimp } \\
\text { ulan }\end{array}$ \\
\hline 0,402 & 0,329 & 2,56 & $\begin{array}{c}1,6 \\
9\end{array}$ & $\begin{array}{c}\text { Signifik } \\
\text { an }\end{array}$ \\
\hline
\end{tabular}

Berdasarkan tabel 8 di atas, ternyata $t_{\text {hitung }}$ $=2,56>\mathrm{t}_{\text {tabel }} 1,69 \alpha=0.05$. Dengan demikian dapat disimpulkan bahwa terdapat hubungan yang berarti (signifikan) antara kemampuan motorik dengan hasil belajarpenjasorkes di SD Negeri 16 Sintoga Kec.Sintuk Toboh Gadang Kabupaten Padang Pariaman,diterima kebenarannya secara empiris.

\section{Pengujian Hipotesis Ketiga $\left(X_{1}\right.$ dan $X_{2}$ dengan $Y$ )}

Hipotesis ketiga yang diajukan dalam penelitian yaitu Terdapat hubungan yang signifikan antara motivasi olahraga dan kemampuan motorik secara bersama-sama denganhasil belajar penjasorkes siswa di SD Negeri 16 Sintoga Kec.Sintuk Toboh Gadang Kabupaten Padang Pariaman.

Pengujian hipotesis ke tiga ini dilakukan menggunakan korelasi ganda. Berdasarkan hasil perhitungan korelasi ganda diperoleh $\mathrm{r}_{\text {hitung }}=$ 0,487 > $\mathrm{r}_{\text {tabel }}$ 0,329 maka Ho ditolak dan $\mathrm{Ha}$ diterima. Artinya terdapat hubungan yang signifikan (berarti) antara motivasi olahraga dan kemampuan motorik secara bersama-sama denganhasil belajarpenjasorkes siswa di SD Negeri 16 Sintoga Kec.Sintuk Toboh Gadang Kabupaten Padang Pariaman.

Untuk lebih jelasnya hasil rangkuman uji t atau uji koefisien korelasi antara motivasi olahraga dan kemampuan motorik secara bersama-sama dengan hasil belajar pendidikan jasmani olahraga dan kesehatan di SD Negeri 16 Sintoga Kec.Sintuk Toboh Gadang Kabupaten 
Padang Pariamantersebut, dapat dilihat pada tabel 9.

Tabel 9. Rangkuman Uji Keberartian Koefisien Korelasi Antara Variabel Motivasi Olahraga Dan Kemampuan Motorik Secara Bersama-Sama Terhadap Hasil Belajar Penjasorkes

\begin{tabular}{|c|c|c|c|c|}
\hline $\begin{array}{l}\text { Koefisien } \\
\text { Korelasi }\end{array}$ & $\begin{array}{c}\text { Koefisien } \\
\text { Determinasi }\end{array}$ & $\begin{array}{c}\mathbf{F}_{\text {hitu }} \\
\text { ng }\end{array}$ & $\begin{array}{c}\mathbf{F} \\
\text { tabel }\end{array}$ & $\begin{array}{c}\text { Kesimp } \\
\text { ulan }\end{array}$ \\
\hline 0,487 & 0,329 & 5,13 & 3,29 & $\begin{array}{c}\text { Signifik } \\
\text { an }\end{array}$ \\
\hline
\end{tabular}

Berdasarkan tabel 9 di halaman sebelumnya, ternyata $\mathrm{t}_{\text {hitung }}=5,13>\mathrm{t}$ tabel 3,29 $\alpha=0.05$. Dengan demikian dapat disimpulkan bahwa terdapat hubungan yang berarti (signifikan) antara motivasi olahraga dan kemampuan motorik secara bersama-sama terhadap hasil belajar penjasorkes di SD Negeri 16 Sintoga Kec.Sintuk Toboh Gadang Kabupaten Padang Pariamandi atas,diterima kebenarannya secara empiris.

\section{Pembahasan}

Hipotesis pertama yang diajukan di dalam penelitian ini adalah Terdapathubungan yang signifikan antara motivasi olahraga dengan hasil belajar penjasorkes siswa di SD Negeri 16 Sintoga Kec.Sintuk Toboh Gadang Kabupaten Padang Pariaman.

Berdasarkan hasil analisis data, ternyata motivasi olahraga mempunyai hubungan secara signifikan dengan hasil belajar penjasorkes di terima kebenarannya secara empiris. Artinya semakin tinggi motivasi olahraga, maka sejalan dengan itu semakin tinggi pula hasil belajar penjasorkes siswa di SD Negeri 16 Sintoga Kec.Sintuk Toboh Gadang Kabupaten Padang Pariaman.

Siswa memperoleh hasil belajar penjasorkes setelah mereka mengikuti proses pembelajaran selama lebih kurang tiga bulan dan kemudian dilakukan evaluasi atau ujian tengah semester oleh guru penjasorkes.

Dengan demikian,jelaslah bahwa hasil belajar penjasorkes siswa masih banyak yang rendah, salah satu variabel yang dapat mempengaruhi hasil belajar penjasorkes tersebut adalah motivasi siswa dalam olahraga. Dari hasil data motivasi olahraga yang diperoleh dari jawaban pertanyaan-pertanyaan yang diajukan sesuai dengan indikator motivasi, maka sebanyak 19 orang motivasi olahraganya dalam kategori sedang, kurang dan kurang sekali.Artinya hanya sebagian siswa yang memiliki motivasi dalam kategori baik sekali dan baik.

Motivasi olahraga dapat diartikan sebagai kekuatan dari dalam diri individu atau yang menggerakan dan mengarahkan, sehingga individu tersebut terjadi perubahan tingkah laku dalam mencapai suatu tujuan.Dalam hal ini tentunya tujuannya adalah berolahraga atau bagaimana tingkah lakunya atau perbuatannya dalam berolahraga. Biasanya siswa yang memiliki motivasi yang tinggi berolahraga akan terlihat dari sikap dan tingkah lakunya, misalnya dia rajin, tekun dan lebih bersemangat, bergairah dan senang dalam berolahraga.

Hipotesis Kedua yang diajukan di dalam penelitian ini adalah Terdapathubungan yang signifikan antara kemampuan motorik denganhasil belajar penjasorkes siswa di SD Negeri 16 Sintoga Kec.Sintuk Toboh Gadang Kabupaten Padang Pariaman.

Berdasarkan hasil analisis data, ternyata kemampuan motorik mempunyai hubungan secara signifikan dengan hasil belajar penjasorkes siswa dan di terima kebenarannya secara empiris. Artinya semakin tinggi kemampuan motorik siswa, maka berkemungkinan semakin baik hasil belajar penjasorkes yang mereka peroleh.

Siswa untuk mendapatkan hasil belajar penjasorkes tersebut harus ikut beberapa macam tes atau evaluasi tentang keterampilan gerak (motorik) dalam olahraga dan pengetahuan tentang kesehatan, sesuai dengan materi pembelajaran yang diberikan guru penjas berdasarkan kurikulum pada semester tersebut.

Dengan demikian dapat dikatakan bahwa hasil belajar penjasorkes tersebut erat kaitannya dengan kemampuan motorik siswa, sehingga dengan kemampuan motorik yang baik mereka dengan mudah melakukan keterampilan gerak dalam pembelajaran penjasorkes.

Dengan memiliki kemampuan motorik baik, siswa tentu mempunyai daya tahan, kecepatan, keseimbangan, kelincahan dan koordinasi gerakan yang baik pula. Hal ini akan sangat berarti dalam mengikuti proses pembelajaran, proses evaluasi pembelajaran dan membawa dampak positif terhadap hasil belajar penjasorkes yang mereka dapatkan, serta telah terbukti memang dalam penelitian ini yang menyatakan terdapat hubungan yang sinigfikan antara kemampuan motorik dengan hasil belajar penjasorkes. 
Hipotesis Ketiga yang diajukan di dalam penelitian ini adalah Terdapathubungan yang signifikan antara motivasi olahraga dan kemampuan motorik secara bersama-sama dengan hasil belajar pendidikan jasmani olahraga dan kesehatan di SD Negeri 16 Sintoga Kec.Sintuk Toboh Gadang Kabupaten Padang Pariaman.

Berdasarkan hasil analisis data, ternyata motivasi olahraga dan kemampuan motorik secara bersama-sama mempunyai hubungan secara signifikan dengan hasil belajar pendidikan jasmani olahraga dan kesehatan di terima kebenarannya secara empiris. Artinya semakin tinggi motivasi olahraga dan semakin baik kemampuan motorik siswa, maka semakin baik pula hasil belajar penjasorkes siswa di SD Negeri 16 Sintoga Kec.Sintuk Toboh Gadang Kabupaten Padang Pariaman.

Meskipun dua variabel yang diteliti yaitu motivasi olahraga dan kemampuan motorik ditemukan mempunyai hubungan secara signifikan dengan hasil belajar penjasorkes siswa dan diterima kebenaranya secara empiris, namun hasil belajar penjasorkes sebagian besar siswa yang menjadi sampel di SD Negeri 16 Sintoga Kec.Sintuk Toboh Gadang Kabupaten Padang Pariaman masih rendah.

Hasil belajar penjasorkes tidak hanya dipengaruhi oleh variabel motivasi olahraga dan kemampuan motorik saja, melainkan banyak variabel lain yang dapat mempengaruhi hasil belajar penjasorkes siswa. Diantaranya sarana dan prasarana pembelajaran, kemampuan guru dalam mengajar dan pemilihan metode dan media yang tepat untuk suatu materi pembelajaran, status gizi dan kesegaran jasmani siswa juga dapat mempengaruhi kesiapan siswa dalam belajar, begitu juga dengan lingkungan belajar.

Lingkungan yang aman dan nyaman bagi siswa untuk melakukan aktivitas bermain misalnya tentu akandapat meningkatkan motivasi siswa dalam belajar, sehingga mereka serius, rajin dan bersemangat mengikuti pembelajaran. Jadi dapat dikatakan bahwa banyak faktor yang perlu diketahui, dipahami dan dimengerti serta dapat mempengaruhi hasil belajar penjasorkes.Semua ini merupakan tanggung jawab bersama, baik siswa, guru dan orang tua, karena orang tua penting memberikan perhatian dan pengawasan terhadap anaknya dalam belajar, sehingga hasil belajar dapat ditingkatkan.
Beradasarkan kepada kesimpulan dalam penelitian ini, maka disarankan kepada:

1. Guru agar lebih meningkatkan kreaktivitas dalam mengajar mungkin dengan mengembangkan model-model pembelajaran, sehingga motivasi siswa dapat ditingkatan.

2. Siswa agar menyadari bahwa belajar merupakan suatu kebutuhan dalam mencapai hasil belajar yang diinginkan, misalnya saja cara belajar dan kemampuan motorik harus ditingkatkan dan sebagainya.

3. Orang tua atau wali murid agar memperhatikan keseimbangan kebutuhan gizi anaknya, karena hal ini berpengaruhi terhadap hasil belajar pendidikan jasmani olahraga dan kesehatan.

4. Pihak sekolah agar melengkapi sarana dan prasarana pembelajaran, sehingga kemampuan motorik siswa dapat ditingkatkan dan mengadakan kerjasama dengan dinas kesehatan tentang pemahaman dan pentingnya keseimbangan gizi dengan aktvitas yang mereka lakukan, sehingga siswa tidak mengalami kelebihan berat badan.

\section{DAFTAR PUSTAKA}

Arsil, 2010. Evaluasi Pendidikan Jasmani Dan Olahraga. Malang: Wineka Media.

Dimyati, 2006. Belajar dan Pembelajaran, Jakarta : Rineke Cipta.

Gusril, 2006. Model Pengembangan Motorik Siswa Sekolah Dasar. Padang: FIKUniversitas Negeri Padang.

Kiram, Yanuar. 2004. Belajar Motorik.Padang: FIK Universitas Negeri Padang.

Lutan, Rusli. 1988. Belajar Keterampilan Motorik : Pengantar Teori dan Metode. Jakarta: Depdikbud.

Mulyasa. 2010. Kurikulum Tingkat Satuan Pendidikan.

Mutohir, T. Cholik (2004). Perkembangan Motorik Pada Masa Anak-Anak, Jakarta“ PPKKO, Dirjen Olahraga Depdiknas.

Riduwan, 2005.Belajar Mudah Penelitian Untuk Guru-Karyawan Dan Peneliti Pemula. Jakrta: Alfabeta. 
Sardiman, 2007. Interaksi dan Motivasi Belajar Mengajar, Jakarta: Raja Grafindo Persada.

Setyobroto, 2002. Psikologi Olahraga. Jakarta: Percetakan Universitas Negeri Jakarta.

Undang-undang Republik Indonesia No. 20, Tahun 2003.Tentang Sistim Pendidikan Nasional. Jakarta: Depdikbud.

Yusuf. 2005. Metodologi Penelitian. Padang: UNP Press. 